\title{
Lumen
}

Selected Proceedings from the Canadian Society for Eighteenth-Century Studies

\section{Sex, Sin and Ideology: The Drama's Gift to the Genesis of the Novel}

\section{Paula R. Backscheider}

Volume 12, 1993

URI : https://id.erudit.org/iderudit/1012574ar

DOI : https://doi.org/10.7202/1012574ar

Aller au sommaire du numéro

Éditeur(s)

Canadian Society for Eighteenth-Century Studies / Société canadienne d'étude du dix-huitième siècle

ISSN

1209-3696 (imprimé)

1927-8284 (numérique)

Découvrir la revue

Citer cet article

Backscheider, P. R. (1993). Sex, Sin and Ideology: The Drama's Gift to the Genesis of the Novel. Lumen, 12, 1-15. https://doi.org/10.7202/1012574ar

Copyright (C Canadian Society for Eighteenth-Century Studies / Société canadienne d'étude du dix-huitième siècle, 1993
Ce document est protégé par la loi sur le droit d'auteur. L'utilisation des services d'Érudit (y compris la reproduction) est assujettie à sa politique d'utilisation que vous pouvez consulter en ligne.

https://apropos.erudit.org/fr/usagers/politique-dutilisation/ 


\section{Sex, Sin and Ideology: The Drama's Gift to the Genesis of the Novel}

[This paper was excerpted from three different chapters of my book, Spectacular Politics: Theatrical Power and Mass Culture in Early Modern England (Johns Hopkins UP, 1993). The following is a little more than the second half of the plenary paper read at the 1991 CSECS Conference.]

Throughout the Restoration and eighteenth century, the theatre was a place for news and commentary on contemporary events and issues. Although royal and noble patronage declined after the first years of the reign of Charles II, the theatres became even more associated with political statement during the turmoil of the 1670s and 1680s. A book could be written about the plays of the Exclusion Crisis, and almost every political event received comment, if not in the plays themselves then in the prologues, epilogues, or printed dedications. Plays, like poems such as John Dryden's Absalom and Achitophel, were forms of news, actually more similar to editorials that both mentioned events and interpreted them. One prologue, A Lenten Prologue refus'd by the Players (1682), read, 'The Stage, like old Rump Pulpits, is become/ The scene of News, a furious Party's drum.'

The theatre became a site worthy of struggle for party control. One playwright compared it to the City of London in 1682, and noted that the Tories' hold on both seemed threatened and tenuous. Factions began to attend the theatre, and evidence is building that play failures we once attributed to such causes as bawdy language in a time of increasingly female theatre attendance should be attributed instead to organized partisans. ${ }^{1}$ By 1682 , however, the stage no longer offered the best forum for political propaganda. The narrow and declining audience was sending the entire group of dedicated party writers in search of new means of reaching the public even before the union of Companies. Dryden, for instance, was publishing a series of poems, and Thomas Durfey issued a pindaric poem, The Progress of Honesty, or a View of Court and City. Aphra Behn was called to account for her epilogue to the anonymous Romulus and Hersilia in 1682, and, although a better poet than Durfey, chose to enter the fray with her first major prose fiction, Love-Letters 
between a Nobleman and His Sister, which was licensed on 20 October 1683, eighteen months after the production of The City Heiress.

At this point, I would like to focus upon Love-Letters between a Nobleman and His Sister and argue two premises: First, that the text may be the answer to a question that comes to all critics of the novel. As John Mullan puts it in Sentiment and Sociability, where is 'the original example of a work to be held up as the dangerous, [indecent], and misleading' example of the novel form? And second, that the text's importance lies in the way it actualizes some of the most important elements in the novel form, the very elements that led the novel to be recognized by the end of the eighteenth century as the 'chief form of moral propaganda' and as 'well-worn channel of access to the public.'

Since 1680 Behn had been one of the most active of a group of Tory playwrights working on the side loyal to the succession of James to the throne. She had effectively used a variety of ways to link the Whig opponents of James with the rebels of the 1640s and 50s. For instance, her play The Roundheads (1682) was based on John Tatham's The Rump (c. 1659), a fact that would strengthen the parallels between the two decades' royalist playwrights and between their representations of the allegedly capricious, self-aggrandizing, ambitious rebels. Thus, she denied respectability to Shaftesbury's cause and raised the spectre of another rebellion and even regicide. As in Oroonoko, Behn inserts herself in the text and in the larger issues. She compares those who would have damned her play 'for its Loyalty' to the factious rebels who 'wou'd be at the Old Game their fore-Fathers play'd' and to the City jury that acquitted Shaftesbury. ${ }^{3}$ Her hopes in the long-term power of her art, also expressed at the end of Oroonoko, are in the dedication to The Lucky Chance (1687), where Behn wrote, 'I have my self known a Man, whom neither Conscience nor Religion cou'd perswade to Loyalty, who with beholding in our Theatre a Modern Politician set forth in all his Colours, was converted, renounc'd his opinion, and quitted the Party' (3:183). Here, too, she repeats the opinion displayed by Charles II's reign: 'Plays and publick Diversions [are]. . . one of the most essential Parts of good Government.' Aligning herself with good people and pointing to commendable conduct, this dedication to the Earl of Rochester, ${ }^{4}$ like the Roundhead's to the duke of Grafton, praises loyalty and service to the king.

Although The Lucky Chance is not as overtly political as plays such as The Roundheads, ${ }^{5}$ Behn describes herself in the dedication as serving the Royal Cause with her 'Heart and Pen' and as working for the most noble, public purposes of the theatre. That she conflates the experience of writing nearly allegorical political plays such as The Roundheads with producing plays apparently about marriage such as The Lucky Chance 
suggests that Behn saw herself constantly engaged in hegemonic discourses and consistently and competitively contesting representations. Others saw her work this way, and a typical tribute published in 1685 reads, 'England has a nobler task for you,/ Not to tame Beasts but the brute Whigs subdue,/ A thing which yet the Pulpit cou'd not do.' Another reads, 'Long may she scourge this mad rebellious Age,/ And stem the torrent of Fanatick rage.' Elegies repeat this theme; a typical one reads, 'Her Royal Master she has follow'd home/ Nor would endure the World when he had lost his Throne. ${ }^{6}$

What readers encountered in Behn's Love-Letters Between a Nobleman and His Sister was a deceptively packaged, sophisticated political satire. Just as she had taken advantage of her plays' sources and been among the most resourceful playwrights of her time in converting conventional forms and theatrical conventions into political vehicles, so she is in her fiction. Obviously allying it with the fashionably popular French romances and continental, amorous epistolary fiction, Behn based it upon a sensational news event and drew as well upon available, more openly political forms. Thus she brought the form that would be called 'novel' into the 'zone of maximally close contact between the represented object and contemporary reality" and also released the form's potential for participation in the immediate life of a civic society. So good is her work that the satire accrues and finally establishes the character and nature of her object rather than striking the reader as satire per se.

The news event that Behn exploited was the scandalous relationship between Ford Grey, later Earl of Tankerville, and his sister-in-law, Lady Henrietta (Harriet) Berkeley. Called 'the most notorious case of seduction in a profligate age, ${ }^{8}$ their romance became a King's Bench trial before Lord Chief Justice Francis Pemberton and was tried again by the partisan periodical press. It also happened that Grey was so trusted a friend and adviser of the duke of Monmouth as to be styled his 'ElectorGeneral' and was part of the Exclusion agitation most closely associated with Anthony Ashley Cooper, first Earl of Shaftesbury.

The Grey scandal was perfect for her purposes. Grey was Presbyterian, and his maternal uncle was the regicide General Henry Ireton. He also had distinguished cavalier forebears, but Behn could play on the rebel blood. She gave Monmouth the name of Cesario and, as in her story, he had been romantically associated with Grey's wife Mary Berkeley both before and after her marriage (Price 24-26, 30-31, 48-49, and 55-58). As early as 1678, Grey was part of a cabal of Whig extremists. He even joined with Shaftesbury, Halifax, Wharton, and Herbert to support the charge that Queen Catherine could be implicated in the Popish Plot ${ }^{9}$ and was one of eight Whigs who tried to have James indicted as a popish recusant. 
By 1683 when Behn was writing Love-Letters, Grey had already been before the Privy Council to explain a cache of weapons stored in his Charterhouse Yard home and was under indictment for his part in inciting Midsummer's Day rioting. On 26 June he had been arrested as a conspirator in the Rye House Plot but had escaped at the door of the Tower. Behn's Part I concludes with a letter from Philander (Grey) to Sylvia (Harriet): 'haste [to me]; bring what news you can learn of Cesario; I would not have him die poorly after all his mighty hopes, nor be conducted to a scaffold with shouts of joy, by that uncertain beast the rabble, who used to stop his chariot-wheels with fickle adorations whenever he looked abroad.' 'Cesario' did not die that year, although the trial and execution of Lord William Russell had led many to believe that Monmouth could not be spared.

Behn locates her fiction in France and casts Cesario and Philander and their largely nameless associates in a series of vague meetings, travels about the country, and amorphous plans. She captures, therefore, the actual indecisiveness and disorganization of Monmouth and the Whigs better than those of her contemporaries who believed in firm leadership, organized plans, or even isolated plots with drastic objectives. Behn focuses her book on the love life of Grey and the Berkeley sisters and depended primarily on details from the trial and from published accounts, both satiric and journalistic. ${ }^{10}$ By doing so, she avoided dangerous reflections on Monmouth and other powerful men, yet she could vilify the type working against the succession of James.

Thus Behn offered a new kind of propaganda at an opportune moment. Since at least the 1640s English readers had been bombarded with political tracts, but Behn created a pleasure vehicle to carry her propaganda. Mikhail Bakhtin has said that the more sophisticated a new form is, the more visible are its 'orchestrated languages' and the more significant the process or re-accentuation (418-21). Behn's text was allied with a number of familiar prose fiction forms, and the most prominent both disguised her political agenda and carried some built in associations with 'history' and with 'truth.' I want to mention only two of these forms.

All of Behn's fictions bear traces of the now often-mentioned but seldom-read multi-volume French romance. This literary kind, like the political memoir and amorous epistle with which Behn's text can also be associated, often claimed to be about actual people and public, political events. For instance, sixty-three people have been identified in Madame de Scudéry's Clélie (Ray 24 and 44n. 4; Haviland 72-74). As the dedication prefaced to the English edition of the French romance Artemenes; or, The Grand Cyrus (English trans., 1653) explains: 
For the Intrigues and Miscarriages of War and Peace are better, many times, laid open and Satyriz'd in a Romance, than in a downright History, which being oblig'd to name the Persons, is often forc' $\mathrm{d}$ for several Reasons and Motives to be too partial and sparing; while such disguis'd Discourses as these, promiscuously personating every Man, and no Man, take their full liberty to speak the Truth. $^{11}$

John Barclay's Argenis (1621) has been described as an instructive allegory because of its representation of historical events and people, and part of the subtitle of Richard Brathwait's Panthalia reads, 'A Discourse Stored with infinite variety in relation to State-Government and Passages of matchless affection gracefully interveined [sic]. ${ }^{12}$ Among other things, these romance authors claimed that the form had earned 'esteeme and Authority' from their representations of 'images of life' and of 'the passions and actions of Men' and that their subject was 'civil life,' that is, the concerns of citizens self-consciously located within a social order. ${ }^{13}$ For decades after the Restoration, compilers of lists of published books included these French-style romances with histories. ${ }^{14}$ This circumstantial evidence suggests that readers accepted authors' claims that their books taught their readers history, associated them with truth as well as imaginative pleasure, and gave them the benefit of experience without the misfortunes of mistakes and unfortunate decisions. ${ }^{15}$ The auditors of Madame la Dauphine in La Princesse de Clèves, for instance, thank her for 'teaching them so much about the English Court' and ask for additional information.

Behn exploited this potential in the romance form and recalled the power of other forms to appear to be artless revelations of the hidden motives and baser natures of their subjects. Lettres portugaise, of course, was certainly known to more people than any of the political memoirs or epistolary satires, and it provided genre identity that assured sales and that also obscured the deeply partisan nature of the text. Just as Tatham and Behn had represented the minds, motives, and characters of Cromwell's inner circle in their plays, Behn presented herself as showing her readers the dangerous and socially irresponsible nature and temperament of Gray and his cohorts. Styling her text as epistolary romance and drawing upon the English traditions of using history to show the 'tempers and principles of the chief actors' of public events ${ }^{16}$ and of creating political propaganda that used exaggerated, fictionalized portraits and allegorical allusions to 'explain' individuals and their actions, Behn produced a text seductive to many kinds of readers.

All of these forms could smoothly contain quite direct propaganda material, and the differences among the three parts of Love-Letters, 
especially when set beside Behn's other late prose fictions, help illuminate some of the reasons the novel became the most powerful form of moral propaganda yet devised. In the first part of Love-Letters, Behn concentrates her attack on the rebels and their cause. Indeed, the text includes a not insignificant number of absolutely direct statements (cf. 33-36). Among the most effective is one in which Sylvia identifies the private with the public: '... your life and glory depend on the frail sacrifice of villains and rebels...; if Sylvia could command, Philander should be loyal as he's noble; and what generous maid would not suspect his vows to a mistress, who breaks 'em with his prince and master!' (16). Behn subtly keeps this idea before her readers and aggressively portrays Philander and the rebels as rash, passionate, and often ridiculous. This was, of course, a traditional representation of rebels, and she shows the justice of the portrayal by making Philander a consistent personality. For instance, Behn has Philander escape once from Sylvia's room in a woman's dress only to be accosted and lewdly propositioned.

Prone to violence, they are often, however, powerless and sometimes even literally impotent. With Sylvia Philander is impotent after he has 'passed all... the loose and silken counterscarps that fenced the sacred fort' (50). This long letter is filled with expressions intended to make Grey ridiculous; 'Philander' writes, 'What god ... Snatched my (till then) never failing power ...?' 'Philander the young, the brisk and gay Philander, who never failed the woman he scarce wished for, never baulked the amorous conceited old, nor the ill-favoured young....' 'wholly abandoning my soul to joy, I rushed upon her, who, all fainting, lay beneath my useless weight, for ... all my power was fled...' (51-53). As Linda Kauffman says, the laughter is 'a theoretical and political strategy; it demystifies the male.... the women imagine a man confronting his own mediocrity ... the aim is a comical operation of dismemberment of the phallus as signifier' (297). Later Brillard doses himself with so much of an aphrodisiac that he becomes ill and cannot perform at all. His inept, crude letters combined with his sexual ineptitude make him the object of derisive laughter. Thus, both he and Philander are represented as being without adequate language and without the other sign of male power, phallic potency. ${ }^{17}$

By the time Behn published the third part, Monmouth had been executed and Charles was dead, and the volume is the rehearsal of a party line. Rather than propaganda it is a hegemonic apparatus participating in the establishment of an ideology. Behn retells a version of the story of the king's hope for reconciliation, of Monmouth's rebellion, and presents a craven, love-besotted end for him. ${ }^{18}$ Grey has resolved to 'prove false to a party, who had no justice and honour on their side, than 
to a King, whom all the laws of heaven and earth obliged him to serve' (446).

Behn's texts, like the royal theatres and the literary forms that are their context, show embryonic movement toward the recognition of the importance of the control of the formation of public opinion. ${ }^{19}$ Characters in Astrea, for instance, ask such questions as 'tell us how you heard it, that we may see how reports do jump' (56). At one point, Celadon asks how reports of his rumored death have been explained, and the shepherd answers, 'it is variously reported ...; some speake as opinion leads them, others according to circumstances and appearance, and some, as others doe report: So it is divers wayes related' (196). He finds out that the most common report is that he fell asleep too close to the river and was swept away, a version that protects the reputations of a number of people. Celadon imagines that those with power 'had prudently invented this report, to take away occasion of talking ill upon the accident.' Through Celadon, D'Urfé points out how reputation, even ethos, is constructed and maintained.

Conversely, writers could do as Behn did and use the same strategies to discredit public figures. Love-Letters includes comments on the crowds that cheered Monmouth and on how that encouraged those that hoped to see him king. At one point Behn has Sylvia observe with heavy sarcasm that 'those glorious chiefs of the faction' waited for the moment when 'the dirty crowd' would 'rise against their king.' Opportunists rather than leaders, dependent on the mob, the rebels seem feminized. Indeed, upon his invasion, 'men of substance' never join Monmouth, but 'if the ladies could have composed an army, he would not have wanted one' $^{\prime}$ (447). By the end of part three, written after Monmouth's execution, the crowd is identified as primarily 'peasants,' 'Reformed Religion' (Nonconformists), and voiceless. In Love-Letters, the mob seems swayed by physical beauty and orchestrated shows of greatness.

Writing near the time when Defoe noted the Dawn of Politicks among the Common Poeple' and he and others remarked on avid readers among, for instance, the chairmen near Whitehall, lowerclassmen gathered 'in the streets,' coffeehouse patrons, and servant maids, Behn describes previously ridiculed segments of the population with open-mindedness and, in fact, had earlier showed considerable insight into art as means of influence. In a dedication she wrote, '[Plays] are secret instructions to the people, in things that 'tis impossible to insinuate into them any other way. 'Tis example that prevails above reason or DIVINE PRECEPTS' (quoted in Goreau 249). Her self-consciousness about the construction of public opinion is impressive here: 
he understood all the useful arts of popularity, the gracious smile and bow, and all those cheap favours that so gain upon hearts; and without the expsense of any thing but ceremony, has made the nation mad for his interest.... As the maiden queen I have read of in England, who made herself idolized by that sole piece of politic cunning, understanding well ... the people; and gained more upon them by those little arts, than if she had parted with all the prerogatives of her Crown. (416)

Monmouth and his advisers staged miniature royal entrées, and townspeople responded. Yet when the rebellion begins, many of those formerly in sympathy with Monmouth's supporters hold back, 'most' 'disgusted' with his claiming the 'title as king' (449). There is a strain in English literature and history that consistently holds that some group often designated metaphorically as the English yeoman bears good sense and will assert itself in time of great national danger. Eighteenthcentury thinkers offered various explanations, but the faith in what John Locke called the 'law of opinion' and Edmund Burke 'real public wisdom' never dies out. Seen as the bulwark of the ancient (and largely mythical) constitution, of laws, morality, and religion, it could assert itself in group actions ranging from petitions to riots. As E.P. Thompson said, 'It is possible to detect in almost every eighteenth-century crowd action some legitimizing notion.... the men and women in the crowd [believed] that they were defending traditional rights or customs; and, in general, that they were supported by the wider consensus of the community' (78; cf. Habermas 54-58 and 64-67).

The general opinion is that Behn's turn to fiction was the result of economic necessity, yet her fiction is daringly original and outspoken, and these qualities are not often characteristic of the work of a writer wishing to be safer, less conspicuous, and quickly solvent. In form, subject matter, and language, her last writings seem to be those of a person grappling with a new national order, of one seeking new modes of political expression and influence, and of a woman conscious of her past achievements and perhaps her approaching death now desiring to write herself into history and into the world. Marxists have theorized that new genres are born when old ones are no longer adequate to express a nation's experiences and aspirations. Bakhtin has argued that the inevitable decay 'of the religious, political and ideological authority connected with [a particular literary] language opens texts to the 'social heteroglossia of national languages' (370), and Marx called the novel a 'simple abstraction,' an apparently and deceptively monolithic category that encloses a complex historical process. More pessimistically, Michael McKeon has said that 'the birth of genres results from a momentary 
negation of the present so intense that it attains the positive status of a new tradition. ${ }^{20}$

It seems clear that Behn produced work representative of such times. With a stroke of bitter realism, Behn notes that Philander was 'very well understood by all good men,' pardoned, and returned to Court (emphasis mine) and reduces Sylvia, who had declared herself 'fit to produce a race of glorious heroes,' to wandering the continent as a whoring shyster. The Fair Jilt, Oroonoko, and The History of the Nun as well as other works written in the last two years of her life are of a piece with this dark roman à clef. These texts tantalize with glimpses of the kinds of human evil waiting to be unleashed. Some is premeditated and machiavellian, some commonplace and 'the way of the world,' some sudden and opportunistic, some inadvertant and regretted, some desperate and impetuous. Perpetrators may prosper, remain in power, fall into destitution and disgrace, or die on the scaffold. Nothing about these fictions is simple. Often about men and women who break solemn vows, they complicate vows and swearing in all the ways people who had had to cope with resolving their consciences to a series of oaths including the Solemn League and Covenant (required of all men over eighteen in 1645) and the conflicting oaths of allegiance, supremacy and nonresistance instituted by the Act of Uniformity in the early 1660 s.

These works, like Otway's late plays, flirt with a vexed world in which 'hero' and 'villain' can seem indistinguishable and whimsical fate decides who will die and who will prosper. Sebastian in Love-Letters, presented initially as a respected senior citizen and statesman, lectures his nephew:

cannot honest men's daughters... serve your turn, but you must crack a Commandment? Why, this is flat adultery; a little fornication in a civil way might have been allowed.... A little pleasure-a little recreation, I can allow: a layer of love, and a layer of business-But to neglect the nation for a wench, is flat treason against the State; and I wish there were a law against all such unreasonable whore-masters-that are statesmen-for the rest it is no great matter. (286)

Oroonoko is surely part of this vexed world. The problems of interpreting Oroonoko as seller of slaves and yet tortured sacrifice to dishonorable slaveholders is but one in the text. Since Behn's authorship of both Oroonoko and Love-Letters was known, her readers would have probably come to the second text prepared for a political allegory and remembering that Cesario was Monmouth. Is 'Caesar,' Oroonoko's slave name, meant to identify Monmouth? Could any of Behn's readers not associate the two? As Laura Brown says, George Marten, brother to 'the great 
Oliverian,' 'deplores the inhumanity' to Oroonoko. She also notes that Royalists are responsible for Oroonoko's death and are divided among themselves over what to do with him. ${ }^{21}$ Monmouth's execution, notably at a time when the king and many noblemen had struggled with policies toward Monmouth and after a rebellion, had been a botched and brutal affair. The Fair Jilt includes another horrendous execution scene, this one even more similar to Monmouth's. Both Love Letters and Oroonoko depict the Caesar character weakened and besotted by love; about Love-Letters it is easy to say that Behn was not impressed by Monmouth's refusal on the scaffold to renounce his mistress Lady Henrietta Wentworth. Philander recovers his immense wealth and is 'splendid' at court. Those in power remain so in Oroonoko. Isabella is guillotined, but Calista and Miranda live to repent.

In her novels, Behn seems at least as seriously engaged with how public opinion is constructed and how it participates in civic discourse as she had been in her plays. Her texts also develop the use of sex as political category, drawing upon the powerful strategies for using sex and gendering of the forms, including the theatre, with which she allies her texts. Philander, for instance, can control neither his fears nor his emotions. Like so many thwarted women in fiction, he 'raves,' 'tears,' curses himself (48) and tells his beloved of his 'thousand soft desires' (93). Both he and Sylvia cross dress, but where he experiences embarrassment, Sylvia rejoices in 'the cavalier in herself' and the 'thousand little privileges, which otherwise would have been denied to women' (117-18). He writes of love, 'those that love not like me will be apt to blame me, and charge me with weakness' (38). In contrast, she writes of politics and at this stage of their relationship evokes the ideology of the restored Charles who was

born a king, and born your king; and holds his crown by right of nature, by right of law, by right of heaven itself; heaven who has preserved him, and confirmed him ours, by a thousand miraculous escapes and sufferings, $\ldots$ and endeared him to us by his wondrous care and conduct, by securing of peace, plenty, ease and luxurious happiness. ... Would you destroy this wonderous gift of heaven? This god-like king, this real good we now possess, for a most uncertain one; and with it the repose of all the happy nation? (36)

Her arguments conclude with the reasoning of Dryden's Absalom and Achitophel.

In the texts from which Behn drew her rhetorical strategies, crossdressing and gendered behavior often signalled the position and power of characters. For some writers, male attire emphasized what they did 
not have. As Mrs. Verbruggen said archly in the epilogue to Trotter's Agnes de Castro, 'I fear these Breeches, Sword, and Manly shew/ Ev'ry way promise more than I can do.' Dryden crossed some of the important speeches of Shakespeare's Antony and Cleopatra, thereby skewing gendered stereotypes of the active and passive sex. Behn's texts, like Dryden's, could reveal that power is allocated not in accordance with biological sex identity but with the perception of gendered, gender-assigned characteristics. As in Dryden's All for Love and other heroic dramas, bad women in Love-Letters make men effeminate. While he lives with Sylvia, Octavio's countrymen 'charge him with a thousand crimes of having given himself over to effeminancy; as indeed he grew too lazy in her arms; neglecting glory, arms, and power, for the more real joys of life; while she ... grows so bold and hardy' (285). Unlike Cleopatra who longs to be a 'household dove,' Sylvia grows 'bold and hardy.' Notably Calista is tall and 'fashioned the most divinely for [masculine] dress of any of her sex' (317), and Cesario's 'Hermione' is masculine in appearance, and she, too, 'weakens' him, and he must be cajoled and shamed into resuming his public role. Thomoso has found him a slave and 'perfectly effeminated into soft woman' (333). Lettres portugaise helped establish uncontrolled emotional outpourings as feminine, and when Behn departs from the 'masculine' examples in the French romances and even in Roger L'Estrange's Five Love-Letters written by a Cavalier (1683), ${ }^{22}$ she effectively used cultural signals for propaganda purposes.

Love-letters Between a Nobleman and His Sister sold briskly and was reprinted and serialized many times. In both 1693 and 1735, two editions of it were published. 'Dangerous, indecent, misleading'-surely those are the words Whigs (and many other good citizens) might have chosen for her novel. Its traces are most obvious to us in scandalous memoirs; in fact, 'warm writing' came to be associated more with political exposés than with love novels, and we think of Delarivière Manley's New Atalantis and The Secret History of Queen Zarah as Love-Letters's nearest relations. Manley, however, could have learned to write the amorous epistolary political fiction from Procopius's first-century The Secret History, which Susan Sontag has called a 'masterpiece of calumny.'

What Behn had done was extend her conception of what part literature could play in the life of a civil society to an emerging form, thereby reaching a new and broader group of consumers. It cannot be forgotten that the popularity of the French romances from which Behn drew so much came to England with Queen Henrietta Maria, and the plays that the courtiers wrote and adapted for her were associated in the minds of many English people with sex, sin, and ideology. The theatre Behn joined had inherited the idea that the stage was a hegemonic vehicle and that spectators, players, and plays were not subject to the ordinary 
categories of sex and judgments of $\sin$. By the end of her career, she could use this knowledge to develop a new form of moral and political propaganda.

For her contemporaries and the next generation, her text was important in demonstrating the infant novel's potential. As John Richetti says of Defoe's H.F., 'the novelistic narrator tends to appropriate for himself and for us what he sees, claims them in the novelistic sense that to narrate is to supply the perception' which supplies the meaning and the identity (96). Her text does indeed occupy a new 'zone of contact,' and that zone is actualized in a way that topical references in the theatre probably were not. Plays were perceived and tested within an aesthetic or conventional concept of form; prose fictions, however, especially those that purported to be 'true,' 'authentic, discovered manuscripts' were to be 'seen through,' to put the reader in contact with the representation (and, allegedly, the represented) rather than with the form. To a large extent, the history of the very earliest novels is the story of a form learning to say dangerous, indecent, and misleading things in acceptable ways. Behn showed that it would be worth learning.

\section{PAULA R. BACKSCHEIDER}

Pepperell Eminent Scholar

Auburn University

\section{Notes}

1 David Roberts, The Ladies 31-32, 107-109, 128-29 and 129n. 5.

2 The phrase is J.M.S. Tompkins's and is quoted in Spacks 175.

3 Citations to Behn's plays are to the Montague Summers edition. Her play was probably acted in December 1681, and 1682 began the years sometimes labelled the 'Stuart revenge,' because of such royal initiatives as the quo warranto actions, the persecution of the Dissenters, and the purging of Whigs from government employment. The Whigs finally lost control of the City in the election of September 1682. The sheriffs of London and Middlesex, however, had been able to pack grand juries and prevent the prosecution of Shaftesbury and Francis Rouse. Both cases were dismissed by an ignoramus verdict, to which Behn refers in her dedication (Jones 217-22).

4 Laurence Hyde, Earl of Rochester and the son of Edward Hyde, Earl of Clarendon, was the most effective director of royal finances before Sidney Godolphin; he served from 1679 to 1685 and was King James's Lord Treasurer in 1685-86 (Jones 48-49, 63-64).

5 The play is, however, full of political allusions and comments. Among them are references to the Quo Warranto proceedings against the City, a dig at the 
Commonwealth, ridicule of those gullible about plots, and sustained satire of City attitudes.

6 'To Astrea on her Poems' in Behn's Miscellany, Being a Collection of Poems by several Hands; the author identifies himself as a country curate, 89 and 87; 'Upon These and Other Excellent Works of the Incomparable Astraea' in her Poems upon Several Occasions (London, 1684) respectively. 'An Elegy Upon the Death of Mrs. A. Behn; The Incomparable Astrea. By a Young Lady of Quality' (licensed 22 April 1689) says, 'Her Royal Master she has follow'd home/ Nor would endure the World when he had lost his Throne.' 'To Madam A. Behn on the Publication of her Poems' by F.N.W. praises her: 'Wou'd you the pattern see/ Of spotless and untainted Loyalty / ... Reade you then Astrea's lines,' Poems upon several Occasions (1684).

7 Mikhail Bakhtin describes this condition as distinctive to the novel form (31). Robert Adams Day says that Behn's Love-Letters was 'the first original piece of long fiction in English entirely in letters' (241).

8 Price 14. My account of Grey's life is largely based on this book and on the historical account in Jones, Country and Court. As late as 1749, accounts of the trial were still being published; see, for example, Whoredom, Fornication and Adultery, detected and laid open, which was cited in The Monthly Review (September 1749) as 'a copy of the proceedings at law, in the affair betwixt lord Grey and lady Harriet Berkeley, and her family; in the reign of K. James II. This is that nobleman and lady whose amours occasioned the publication of those two celebrated volumes, entitled love-letters betwixt a nobleman and his sister; with the history of their adventures.' The notice also mentions that Love-Letters was 'generally' attributed to Behn (394).

9 A disreputable informer, William Bedloe was the first to implicate the queen, but it was not until Oates claimed that he had seen letters of thanks for large sums of money to her from the Jesuits and that she had known of a plan to poison the king that the Whigs began to try to discredit her (Mackay 208-28; Hutton 362-63, 377-78.)

10 It is important to remember that the authority and veracity of even the 'newspaper' press was affected by the prominence of the families, their political positions, and the partisan nature of the press. Among the papers that reported on the event were The Loyal Protestant and True Domestick Intelligence and Observator. The London Gazette carried Lord Berkeley's advertisement and brief notices about the trial.

11 Artamenes; or, The Grand Cyrus, That Excellent Romance in Ten Parts. Written By that Famous Wit of France, Monsieur de Scudery, Governour of Nostre-Dame [sic] Englished by F.G., Esq; London: Darby, Roberts, Griffin, Everingham, 1691, from 'To the Reader.' Compare Humphrey Moseley's similar statement in 'The Stationer to the Reader' (London, 1653): 'our Author in this hath so laid his Sceans, as to touch upon the greatest Affairs of our Times: for, Designs of War and Peace are better hinted and cut open by a Romance, than by down-right Histories; which, being bare-fac'd, are forc'd to be often too modest and sparing; when these disguiz'd Discourses, freely personating every man and no man, have liberty to speak out.' Bakhtin calls it a roman à clef (96).

12 Readers would have 'met' 'familiar situations and incidents ... at every turn' in Astrea (Upham 310). For a still-useful discussion of some of the historical elements of the romances, see Haviland 70, 72-75, and 100-116. Haviland calls Panthalia a thinly disguised history of England (110-11). 
13 See, for instance, Honoré D'Urfé's 'To the Reader' prefixed to Part I, Book I, of Astrea, 'Translated by a Person of Quality' (London, 1657). These fictions were extremely popular in England at this time. In addition to the publication of new editions of La Calprenède's and Scudéry's romances, new ones such as the anonymous Heliodorus (1686), Adelaide (1686), and Cynthia (1687) were appearing.

14 See, for example, Robert Clavel, The General Catalogue of Books Printed in England (London, 1680), which extended his A Catalogue of all the Books printed in England since the Dreadful Fire of London, in 1666 To the End of Michaelmas Term, 1672 (London, 1673). In this classified list, The History of the Late Wars in Denmark appears beside Cassandra and Cleopatra. The same is true of the third edition.

15 The Druid in Astrea for instance, tells Silvia that she can learn to be armed 'against the forces' of love, 'lest being too secure in your opinion of that which you judge impossible, you should be surprised before you be prepared...' (1: 157).

16 The quotation is from the preface to Gilbert Burnet's History of His Own Time, 6 vols. (Oxford: Clarendon, 1823) 5.

17 In the introductory chapter of her discussion of women and language, Margaret Homans quotes Lacan, "The phallus is the privileged signifier of that mark in which the role of the logos is joined with the advent of desire' (7).

18 For her propagandistic retelling, see 280-81, 341, 347, 447-60.

19 This section is informed by Jürgen Habermas, The Structural Transformation of the Public Sphere.

20 McKeon 268. In 1689, Behn wrote,

While my sad Muse the darkest Covert Sought,

To give a loose to Melancholy Thought;

Opprest, and sighing with the Heavy Weight

Of an Unhappy dear Lov'd Monarch's Fate;

A lone retreat, on Thames's Brink she found,

All of a suddain thro' the Woods there Rung,

Loud Sounds of Joy that Jo Peans [sic] Sung.

Maria! Blest Maria! was the Theam

The Muses all upon this Theam Divine,

Tun'd their best Lays, the Muses all, but mine,

Sullen with Stubborn Loyalty she lay....

The poem, 'A Congratulatory Poem to her Sacred Majesty Queen Mary upon her Arrival in England' (1689), goes on to pay tribute to Mary as bearing her father's 'face' and reconciling the English people (Uncollected Verse 159-60).

21 Brown 56-58. I obviously disagree with her identification of Oroonoko with Charles I.

22 This publication may have appeared too late to have influenced Behn's work; Day notes that Astrea contains 129 letters, Artamenes 117, and Clelia 121 (216n. 23). This perception of gendered discourse became more generally accepted in the eighteenth century; Mary Wollstonecraft, for example, discusses a number of gendered, and incidentally hegemonic, language systems in A Vindication of the Rights of Woman (1792). She writes self-consciously of how she intends 'to persuade by the force of' her arguments, avoid women's 'flowery diction,' and discourse that creates 'a kind of sickly delicacy' (Introduction, and see also ch. 5, sec. 2). 


\section{Secondary Sources Cited}

Bakhtin, Mikhail. The Dialogic Imagination. Trans. Caryl Emerson and Michael Holquist. Austin: U of Texas P, 1981.

Behn, Aphra. Love-Letters between a Nobleman and his Sister. Introd. Maureen Duffy. London: Penguin-Virago, 1987.

-. The Uncollected Verse of Aphra Behn. Ed. Germaine Greer. Stump Cross, Essex: Stump Cross Books, 1989.

—. The Works of Aphra Behn. Ed. Montague Summers. 6 vols. London: Heinemann, 1915.

Brown, Laura. 'The Romance of Empire.' The New Eighteenth Century. Ed. Felicity Nussbaum and Laura Brown. New York: Methuen, 1987. 41-61.

Day, Robert Adams. Told in Letters. Ann Arbor: U of Michigan P, 1986.

Goreau, Angeline. Reconstructing Aphra. New York: Dial P, 1980.

Habermas, Jürgen. The Structural Transformation of the Public Sphere. Trans. Thomas Burger. Cambridge: MIT P, 1991.

Haviland, Thomas. 'The Roman de Longue Haleine on English Soil.' Diss. U of Pennsylvania, 1931.

Hutton, Ronald. Charles the Second. Oxford: Clarendon, 1989.

Homans, Margaret. Bearing the Word: Language and Female Experience. Chicago: U of Chicago P, 1986.

Jones, J.R. Country and Court. Cambridge, MA: Harvard UP, 1979.

Kauffmann, Linda. Discourses of Desire. Ithaca: Cornell UP, 1986.

Mackay, Janet. Catherine of Braganza. London: John Long, 1937.

McKeon, Michael. The Origins of the English Novel, 1600-1740. Baltimore: Johns Hopkins UP, 1987.

Mullan, John. Sentiment and Sociability: The Language of Feeling in the Eighteenth Century. Oxford: Oxford UP, 1988.

Price, Cecil. Cold Caleb: The Scandalous Life of Ford Grey. London: Andrew Melrose, 1956.

Ray, William. Story and History: Narrative Authority and Social Identity. Cambridge: Basil Blackwell, 1990.

Richetti, John. Defoe's Narratives: Situations and Structures. Oxford: Clarendon, 1975.

Roberts, David. The Ladies: Female Patronage of Restoration Drama, 1660-1700. Oxford: Clarendon, 1989.

Spacks, Patricia Meyer. Desire and Truth: Functions of Plot in Eighteenth-Century English Novels. Chicago: U of Chicago P, 1990.

Thompson, E.P. 'The Moral Economy of the English Crowd in the Eighteenth Century.' Past and Present 50 (1971): 76-136.

Upham, Alfred. The French Influence in English Literature. New York: Columbia UP, 1911. 